\title{
Får pasienter med Bells parese riktig behandling?
}

\author{
Behandling av Bells parese har vært omdiskutert i flere tiår. Det foreligger nå god vitenskapelig dokumentasjon \\ som viser at tidlig behandling med prednisolon øker antallet pasienter som blir friske, og reduserer antallet \\ som får vedvarende plager. På tross av dette får nesten halvparten fortsatt ikke noen form for behandling.
}

Bells parese er en akutt, ensidig perifer facialisparese med ukjent årsak. Sykdommen kjennetegnes av plutselig ensidig svakhet eller lammelse av ansiktsmuskulaturen, som medfører at ansiktet henger. Pasientene opplever problemer med å bevege munnen og å lukke øyet. Andre vanlige symptomer er smerter rundt øret og nedsatt smaksans på samme side som paresen.

Insidensen av Bells parese er ca. 30-40 per 100000 innbyggere (1), noe som tilsvarer 1 500-2 000 pasienter per år i Norge. Sykdommen forekommer i alle aldersgrupper, men insidensen øker med alderen (1). Omtrent $70 \%$ av pasientene får normal nervefunksjon i løpet av seks måneder uten noen form for behandling, mens de resterende $30 \%$ får sekvele med permanent svakhet av ansiktsmuskulaturen, muskelkontraktur og/eller synkinesier (2).

Bells parese utgjør ca. $70 \%$ av tilfellene med perifer facialisparese (2). Bells parese er en eksklusjonsdiagnose som først stilles når andre årsaker til akutt perifer facialisparese er utelukket. De hyppigste kjente årsakene til perifer facialisparese er herpes zoster-infeksjon, nevroborreliose, akutt og kronisk otitis media, traume mot nerven og maligne tumorer i parotis. Ved en perifer facialisparese er alle nervegrenene på den paretiske siden påvirket, til forskjell fra en sentral facialisparese der nervefunksjonen i pannen er intakt.

Det foreligger flere teorier for å forklare årsaken til Bells parese. En foreslått årsak er reaktivering av herpes simplex-virus i tilslutning til facialisnerven (3). En autoimmun årsak er også blitt diskutert. En annen teori er hevelse av nerven utløst av en inflammatorisk reaksjon med sekundær iskemi. Dette stemmer med funn fra MRstudier som har vist at det foreligger et ødem i facialisnerven i tinningbeinet (4).

\section{Prednisolon gir god effekt}

For å forkorte tilhelingstiden og øke antallet pasienter som får tilbake nervefunksjonen, er flere behandlingsalternativer blitt undersøkt. Antivirale midler er blitt brukt - basert på teorien om at herpes simplex-virus kan være årsak til paresen. Kortisonbehandling er gitt i flere studier for å minske den inflammatoriske reaksjonen som sannsynligvis foreligger, og dermed begrense nerveskaden. Frem til begynnelsen av 2000-tallet var det utført et stort antall mindre studier med begge legemidlene uten at det forelå evidens for at noen av dem hadde effekt $(5,6)$.

Klinisk praksis har følgelig vært varierende, der man i noen land ikke har gitt noen behandling, mens man andre steder har gitt kortison og/eller antivirale midler.

På 2000-tallet er det imidlertid blitt utført flere større randomiserte studier der man har undersøkt effekten av kortison og antivirale midler hos voksne med Bells parese. Det foreligger nå dokumentasjon med evidensgrad A for at behandling med pred-

\section{«Bells parese utgjør ca. $70 \%$ av tilfellene med perifer facialis- parese»}

nisolon forkorter tilhelingstiden og øker andelen pasienter som blir friske. Flere metaanalyser, fra blant annet Cochranegruppen, er blitt publisert. Der anbefaler man prednisolon innen 72 timer til voksne pasienter $(7,8)$. Behandling hos barn er imidlertid ikke tilstrekkelig studert. De siste årene er det også publisert oversiktsartikler med retningslinjer for utredning og behandling der man anbefaler tidlig behandling med prednisolon (9-11).

Disse metaanalysene og oversiktsartiklene bygger i stor grad på en skotsk og en skandinavisk studie. Den skotske studien er en randomisert, placebokontrollert, dobbeltblindet studie, der man undersøkte effekten av prednisolon, aciklovir og kombinasjonen av prednisolon og aciklovir mot placebo hos 551 pasienter (12). Det ble gitt prednisolon 50 mg per døgn og aciklovir $2000 \mathrm{mg}$ per døgn i ti dager. Resultatene ble publisert i 2007 og viste signifikant høyere antall pasienter som ble friske i prednisolongruppen etter tre og ni måneder. Aciklovir viste ingen effekt, verken som monoterapi eller i kombinasjon med prednisolon (12).

Parallelt med den skotske studien ble en tilsvarende studie utført i Sverige og Finland (13). Totalt ble 839 pasienter randomisert til behandling med placebo, prednisolon, valaciklovir eller kombinasjonsbehandling med prednisolon og valaciklovir. Det ble gitt $60 \mathrm{mg}$ prednisolon per døgn i fem dager og deretter nedtrappet med $10 \mathrm{mg}$ per dag over ytterligere fem dager. Valaciklovir ble gitt i dosen 1 gram tre ganger daglig i sju dager. Resultatene ble publisert i 2008 og viste signifikant kortere tilhelingstid og større andel med normal nervefunksjon etter 12 måneder i prednisolongruppen. Antiviral behandling med valaciklovir hadde ingen signifikant effekt på tilheling sammenliknet med placebo (13).

I begge studiene ble behandlingen startet innen 72 timer fra debut av facialisparesen. Subgruppeanalyser fra den skandinaviske studien tyder på at prednisolon har effekt uansett alvorlighetsgrad av paresen og i alle aldersgrupper over 18 år. I tillegg tyder resultatene på at prednisolon er mer effektivt hvis det blir gitt innen 48 timer $(14,15)$.

\section{Korrekt behandling?}

For å undersøke effekten av disse studiene på behandlingspraksis ved Bells parese, ble det nylig gjennomført en studie der man gikk gjennom elektroniske journaler fra 640 allmennpraktikere i Storbritannia for tidsperioden 2001 til 2012. Studien viste at det var en økning i forskrivelse av prednisolon til pasienter med Bells parese etter 2007 , men at $44 \%$ av pasientene fortsatt ikke fikk noen form for behandling i 2012 (1). Noen av disse pasientene hadde trolig andre sykdommer som gjorde at prednisolon ikke ble gitt. Prednisolon bør brukes med forsiktighet ved blant annet magesår, psykoser, diabetes mellitus, nyre- og hjertesvikt og visse infeksjoner. Det er imidlertid sannsynlig at disse relative kontraindikasjonene bare kan forklare en liten andel av de $44 \%$ som ikke fikk behandling (1). Vår forklaring, i likhet med Morales og medarbeidere (1), til at mange pasienter ikke får rett behandling, er at resultatene av de kliniske studiene ikke har nådd frem til behandlende helsepersonell. Dette viser hvor viktig det er at resultater fra internasjonale studier også spres på et nasjonalt nivå for å sikre pasientene rett behandling.

Det foreligger ingen liknende data fra Norge, men vi mener at det sannsynligvis er mange pasienter som ikke får korrekt behandling også her, og som dermed har $ø \mathrm{kt}$ risiko for permanent nedsatt nervefunksjon med de funksjonelle og psykososiale plagene det medfører. 
Thomas Berg (f. 1975) er ph.d. og overlege ved Avdeling for plastikk og rekonstruktiv kirurgi, Oslo universitetssykehus, Rikshospitalet. Forfatter har fylt ut ICMJE-skjemaet og oppgir ingen interessekonflikter.

Lars Jonsson (f. 1952) er docent og overlege ved Öron-, näs- och halskliniken, Akademiska sjukhuset Uppsala, Sverige.

Forfatter har fylt ut ICMJE-skjemaet og oppgir ingen interessekonflikter.

\section{Litteratur}

1. Morales DR, Donnan PT, Daly F et al. Impact of clinical trial findings on Bell's palsy management in general practice in the UK 2001-2012: interrupted time series regression analysis. BMJ Open 2013; 3: e003121.

2. Peitersen E. Bell's palsy: the spontaneous course of 2,500 peripheral facial nerve palsies of different etiologies. Acta Otolaryngol Suppl 2002; 549: 4-30.

3. Murakami S, Mizobuchi M, Nakashiro Y et al. Bell palsy and herpes simplex virus: identification of viral DNA in endoneurial fluid and muscle. Ann Intern Med 1996: 124: 27-30.

4. Schwaber MK, Larson TC 3rd, Zealear DL et al. Gadolinium-enhanced magnetic resonance imaging in Bell's palsy. Laryngoscope 1990; 100: 1264-9.

5. Allen D. Dunn L. Aciclovir or valaciclovir for Bell's palsy (idiopathic facial paralysis). Cochrane Database Syst Rev 2004; nr. 3: CD001869.

6. Salinas RA, Alvarez G. Ferreira J. Corticosteroids for Bell's palsy (idiopathic facial paralysis). Cochrane Database Syst Rev 2004: nr. 4: CD001942.

7. Gronseth GS, Paduga R. Evidence-based guideline update: steroids and antivirals for Bell palsy: report of the Guideline Development Subcommittee of the American Academy of Neurology. Neurology 2012; 79: 2209-13.

8. Salinas RA, Alvarez G, Daly F et al. Corticosteroids for Bell's palsy (idiopathic facial paralysis). Cochrane Database Syst Rev 2010; nr. 3: CD001942.

9. Baugh RF, Basura GJ, Ishii LE et al. Clinical practice guideline: Bell's Palsy executive summary. Otolaryngol Head Neck Surg 2013; 149: 656-63.

10. McCaul JA, Cascarini L, Godden D et al. Evidence based management of Bell's palsy. Br J Oral Maxillofac Surg 2014; 52: 387-91

11. Eviston TJ, Croxson GR, Kennedy PG et al. Bell's palsy: aetiology, clinical features and multidisciplinary care. J Neurol Neurosurg Psychiatry 2015; 0 : $1-6$

12. Sullivan FM, Swan IR, Donnan PT et al. Early treat ment with prednisolone or acyclovir in Bell's palsy. N Engl J Med 2007; 357: 1598-607.

13. Engström M, Berg T, Stjernquist-Desatnik A et al. Prednisolone and valaciclovir in Bell's palsy: a randomised, double-blind, placebo-controlled, multicentre trial. Lancet Neurol 2008; 7 $993-1000$

14. Axelsson S, Berg T, Jonsson L et al. Prednisolone in Bell's palsy related to treatment start and age. Otol Neurotol 2011; 32: 141-6.

15. Axelsson S, Berg T, Jonsson L et al. Bell's palsy the effect of prednisolone and/or valaciclovir versus placebo in relation to baseline severity in a randomised controlled trial. Clin Otolaryngol 2012; 37: 283-90.

Mottatt 24.2. 2015, første revisjon innsendt 4.5. 2015, godkjent 10.5. 2015. Redaktør: Hanne Støre valeur.

Publisert først på nett. 